\title{
A Strategy for a Thai Hospital
}

\author{
Ameen Talib \\ Head, Applied Projects. School of Business \\ Singapore University of Social Sciences
}

\begin{abstract}
The paper proposes a strategy for a Hospital in Thailand. These strategies are chosen based on the goal to be achieved, our current situation and understanding the environment we working in. Prior to adopting any strategies we need to (a) identify the strategic goals (b) identify where we are including our strength and weakness, (c) understand the environment we working in including competitors and economic environment, and (d) suggest a strategy that will achieve the goal and take us from where we are to where we want to go. The strategy needs to work within the environment we are in and take into consideration our current status.

The paper is useful for those involved in business strategy.
\end{abstract}

Keywords: Thailand, Strategy, Aikchol

\section{INTRODUCTION}

This paper proposes strategies for Aikchol hospitals. The report and recommendations are based on publicly available information and no discussions were held with management to ascertain any specific goals or objectives.

The first section introduces Aikchol for a general understanding of the business. Section 2 introduces Aikchol vision in an attempt to identify the strategic goals. Any recommended strategy must align and attain strategic goals. The standard objective (goal) of any firm is to maximise shareholders wealth in the long term. However many firms would also have other specific goals. Section 3 informs the reader of the current situation and status of Aikchol. That section provides a brief analysis of where Aikchol is; as the strategies will get Aikchol from where it is to where it wants to go i.e. the strategic goals.

Section 4 deals with the environmental scan. Prior to adopting any strategies we need to (a) identify the strategic goals (b) identify where we are including our strength and weakness , (c) understand the environment we working in including competitors and economic environment, and (d) suggest a strategy that will achieve the goal and take us from where we are to where we want to go. The strategy needs to work within the environment we are in and take into consideration our current status.

Section 5 introduces the 2 strategies recommended to achieve the goal. These strategies are chosen based on the goal to be achieved, our current situation and understanding the environment we working in. This section also includes a brief justification for the strategies.

\section{SECTION 1: Aikchol Hospital Public Company Limited:}

Founded by the visionary Dr. Aikapoj Vanich, who anticipated rapid development in Chon Buri province and the Eastern Seaboard, Aikchol's forerunner "Aikchol Hospital Company Limited" started its business in 1978 with 22 million Baht in registered capital. Responding to his concerns about people's health issues and their increasing needs for Hospital services, Aikchol was Chon Buris first private hospital 
Aikchol Hospital Public Company Limited is a Thailand-based company engaged in hospital business. The principal activities are the provision of full hospital services including diseases protection, medical treatment, and health strengthening and health rehabilitation services. The Company offers clinic centre and healthcare services, such as general medicine clinic, nephrology clinic, neurological clinic, chest clinic, cardiology clinic, general surgery clinic, orthopaedic clinic, cryosurgical clinic, plastic surgery clinic, neurosurgery clinic, psychiatry clinic, ear, nose, throat clinic, dermatology clinic, paediatric clinic, allergy clinic, dental clinic, medical check-up clinic and physical therapy.

Aikchol Hospital Public Company limited operates 2 hospitals; Aikchol hospital with 262 beds and Aikchol 2 Hospital with 100beds. In 2016 the company purchased land to Aikchol Hospital for future expansion.

\section{SECTION 2: The Vision and Goal:}

Aikchol vision is to be Exceptional Excellent Hospital by the year 2019.

They state in their mission to

1. Provide one-stop healthcare services with standard quality

2. Provide treatments for complex diseases by teams of professional physicians and qualified staff members and with modern devices and advanced technologies.

3. Minimize waiting time.

Aikchol Hospital focuses on all types of patients, both general and with group of patients with private insurance. On the other hand Aikchol 2 Hospital services patients with Social Security Scheme, Company contract, Workmen Compensation Fund, Thai compulsory car/ motor insurance as well as general customers. The target group of workers from nearby industrial estates that has feasible access to the hospital.

Aikchol Hospital aims to expand its customer base to encompass foreigners as this year foreign patients from foreign organizations have been treated by the hospital. Health trends and government policies are therefore important factors, while wellness trends have encouraged people to go to fitness gyms, seeking good food and good health, which is something that all people should live by in the current world.

The business expansion of Aikchol Hospital is proportional to the growth of the economy because the economic status of the middle-class has also improved. Healthcare clients have spread to every corner of the city. Foreign customers of Aikchol Hospital include seasonal groups, and recurrent patients in health rehabilitation who, though small in size, have confidence in the quality and expertise provided by the hospital.

With Aikchol Hospital being located in Chon Buri city, surrounded by government offices, schools, public hospitals as well as being close to Amata Industrial Estate and several housing projects, the hospital attracts a variety of business customers. Aikchol hospital expanded its customer base to include foreign clients by its esteem distinction a JCI accredited standard with many expert doctors on specialized clinics.

At the same time, the opening up of the ASEAN free trade area has revived the business sector, leading to a movement of health personnel both in and out of the country, with requirement for an overall increase of the number of ASEAN workers in Thailand. However, the management of manpower in the health care sector still remains a problem, as there is a lack of personnel in health services, and inefficient distribution in both the government and private sectors, as well as in the city and rural areas. (Annual Report 2017) 


\section{SECTION 3: Current Situation:}

For the fiscal year ended 31 December 2017, Aikchol Hospital Public Company Limited revenues decreased 2\%. Net income decreased 30\% to BAH127.9M. Revenues reflect a decrease in demand for the Company's products and services due to unfavourable market conditions. Aikchol bed occupancy is just below the $70 \%$ mark while the industry median is $80 \%$.

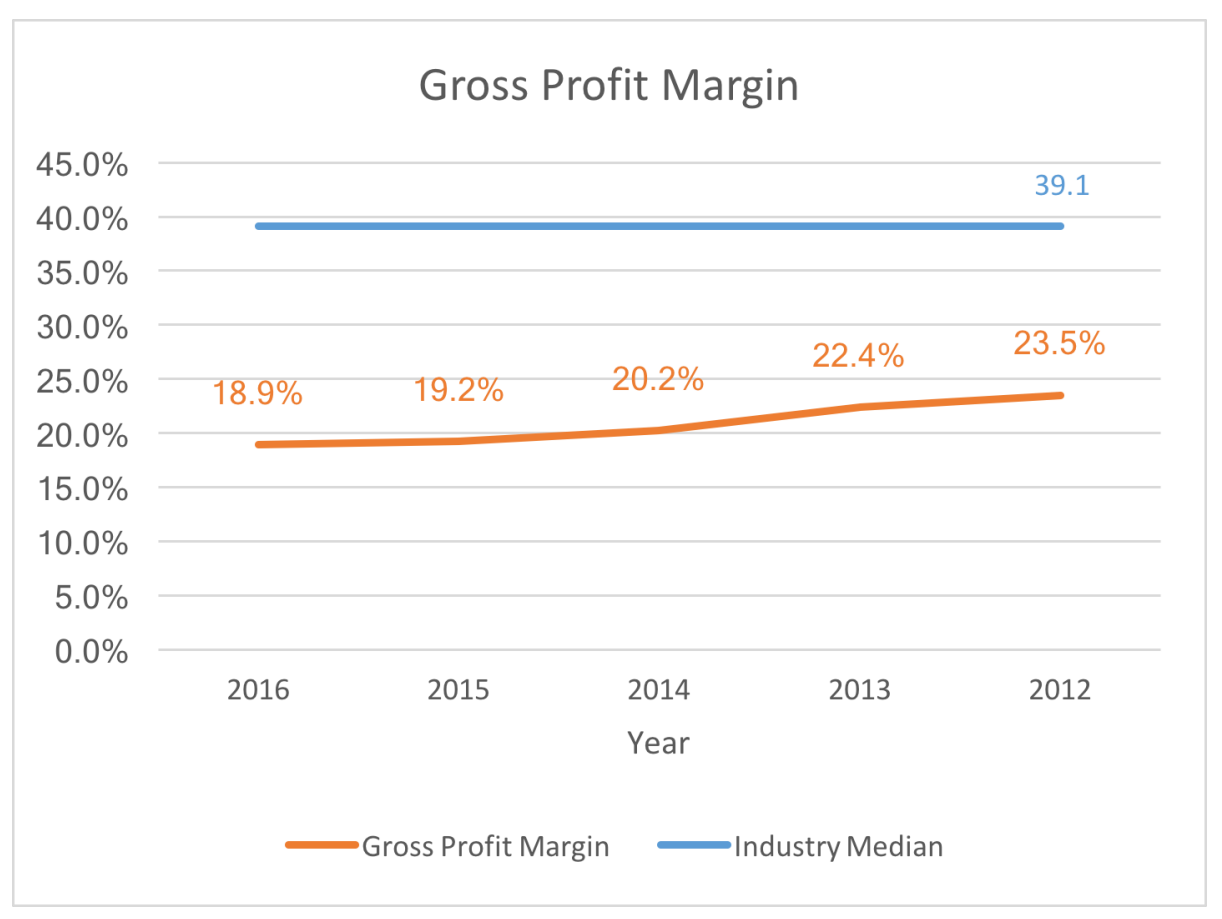




\begin{tabular}{|c|c|c|}
\hline Name & Company & Industry \\
\hline \multicolumn{3}{|l|}{ Valuation Ratios } \\
\hline P/E Ratio TTM & 25.32 & 45.99 \\
\hline Price to Sales TTM & 2.13 & 6.56 \\
\hline Price to Cash Flow $M R Q$ & 63.25 & 137.68 \\
\hline Price to Free Cash Flow TTM & 22.5 & 94.34 \\
\hline Price to Book $M R Q$ & 2.22 & 7.2 \\
\hline Price to Tangible Book $M R Q$ & 2.32 & 8.91 \\
\hline \multicolumn{3}{|l|}{ Profitability } \\
\hline \multicolumn{3}{|c|}{$\begin{array}{l}\text { Profitability: TTM vs } 5 \text { Year Average Margins } \\
\text { |TTM (\%) }\end{array}$} \\
\hline \multicolumn{3}{|c|}{$\begin{array}{l}\text { Gross margin Operating margin Pre-tax margin Net Profit margin0\%5\%10\%15\%20\% } \\
\text { Net Profit margin }\end{array}$} \\
\hline \multicolumn{3}{|l|}{ TTM (\%)8.26\% } \\
\hline \multicolumn{3}{|l|}{5 Year Avg. (\%)11.24\% } \\
\hline Gross margin TTM & $14.95 \%$ & $33.39 \%$ \\
\hline Gross Margin $5 Y A$ & $19.04 \%$ & $33.37 \%$ \\
\hline Operating margin $T T M$ & $10.24 \%$ & $18.15 \%$ \\
\hline Operating margin $5 Y A$ & $13.66 \%$ & $18.21 \%$ \\
\hline Pre-tax margin $T T M$ & $10.24 \%$ & $19.12 \%$ \\
\hline Pre-tax margin $5 Y A$ & $13.98 \%$ & $19.86 \%$ \\
\hline Net Profit margin TTM & $8.26 \%$ & $15.59 \%$ \\
\hline Net Profit margin $5 Y A$ & $11.24 \%$ & $16 \%$ \\
\hline \multicolumn{3}{|l|}{ Management Effectiveness } \\
\hline \multicolumn{3}{|c|}{$\begin{array}{l}\text { Management Effectiveness: TTM vs } 5 \text { Year Average Margins } \\
\text { |TTM (\%) }\end{array}$} \\
\hline \multicolumn{3}{|l|}{5 Year Avg. (\%) } \\
\hline Return on Equity TTM & $8.85 \%$ & $17.48 \%$ \\
\hline Return on Equity $5 Y A$ & $13.25 \%$ & $19.61 \%$ \\
\hline Return on Assets TTM & $7.36 \%$ & $10.5 \%$ \\
\hline Return on Assets $5 Y A$ & $11.24 \%$ & $11.46 \%$ \\
\hline Return on Investment TTM & $8.5 \%$ & $13.08 \%$ \\
\hline Return on Investment $5 Y A$ & $12.75 \%$ & $14.33 \%$ \\
\hline \multicolumn{3}{|l|}{ Growth } \\
\hline EPS(MRQ) vs Qtr. 1 Yr. Ago & $21.61 \%$ & $6.29 \%$ \\
\hline EPS(TTM) vs TTM 1 Yr. Ago & $-29.95 \%$ & $4.47 \%$ \\
\hline 5 Year EPS Growth & $-5.84 \%$ & $17.33 \%$ \\
\hline Sales (MRQ) vs Qtr. 1 Yr. Ago & $-1.23 \%$ & $10.03 \%$ \\
\hline
\end{tabular}




\begin{tabular}{|c|c|c|}
\hline Name & Company & Industry \\
\hline Sales (TTM) vs TTM 1 Yr. Ago & $-2.38 \%$ & $10.31 \%$ \\
\hline 5 Year Sales Growth & $4.13 \%$ & $16.86 \%$ \\
\hline 5 Year Capital Spending Growth & $-8.99 \%$ & $31.94 \%$ \\
\hline \multicolumn{3}{|l|}{ Financial Strength } \\
\hline Quick Ratio $M R Q$ & 3.04 & 1.29 \\
\hline Current Ratio $M R Q$ & 3.23 & 1.38 \\
\hline LT Debt to Equity $M R Q$ & $0 \%$ & $33 \%$ \\
\hline Total Debt to Equity $M R Q$ & $0 \%$ & $44.82 \%$ \\
\hline \multicolumn{3}{|l|}{ Efficiency } \\
\hline Asset Turnover TTM & 0.89 & 0.68 \\
\hline Inventory Turnover TTM & 32.78 & 35.55 \\
\hline Revenue/Employee TTM & - & $1.39 \mathrm{M}$ \\
\hline Net Income/Employee TTM & - & $80.41 \mathrm{~K}$ \\
\hline Receivable Turnover TTM & 9.84 & 11.36 \\
\hline
\end{tabular}

TTM = Trailing Twelve Months 5YA = 5-Year Average MRQ = Most Recent Quarter

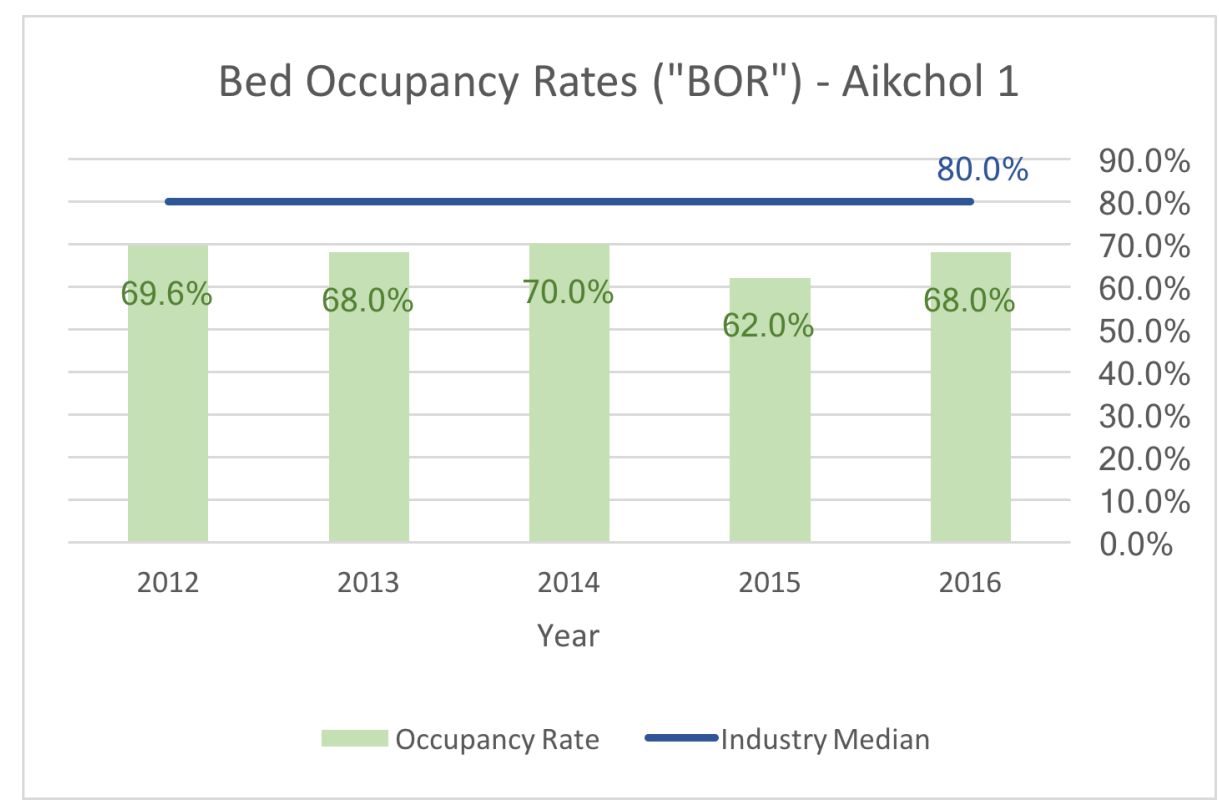




\section{SWOT ANALYSIS}

\begin{tabular}{|c|c|}
\hline Strengths & Weakness \\
\hline 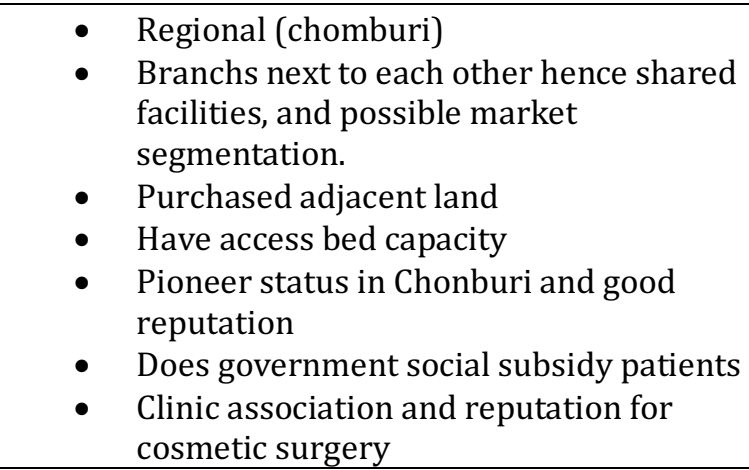 & $\begin{array}{ll}\text { - } & \text { Regional (not Bangkok) } \\
\text { - } & \text { Difficulty in staffing. } \\
\text { - } & \text { Limited in Geographical spread (both } \\
\text { - } & \text { Thaspitals next to each other) } \\
\text { - } & \text { Government subsidized patients low } \\
\text { - } & \text { margins } \\
\text { - Website in Thai only }\end{array}$ \\
\hline Opportunities & Threats \\
\hline 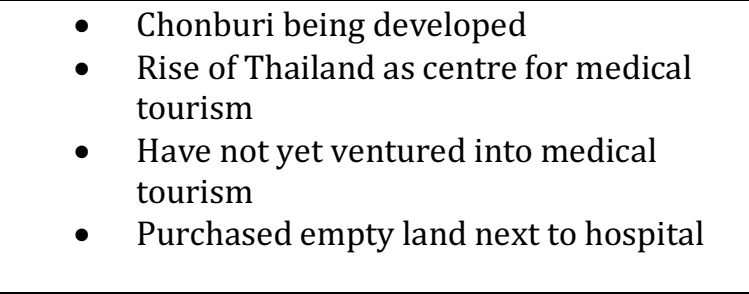 & $\begin{array}{l}\text { - Significant new entrants and competition } \\
\text { in Chonburi } \\
\text { - Drop in Middle East medical tourists } \\
\text { hence likelihood of Brumbrand shifting } \\
\text { away from Middle East patients focus. } \\
\text { - Chonburi industrial and commercial } \\
\text { plans do not succeed. }\end{array}$ \\
\hline
\end{tabular}

\section{SECTION 4: Environment Scan}

Chonburi is the capital of Chonburi Province and Mueang Chonburi District in Thailand. It is about $100 \mathrm{~km}$ south-east of Bangkok, on the coast of the Gulf of Thailand. The name means "city of water".

Chonburi, along with other areas along the coast to Pattaya, forms a conurbation known as the Pattaya-Chonburi Metropolitan Area. Recognized as the gateway to various eastern coastal provinces, Chon Buri is one of the three provinces under the Eastern Seaboard Development Program, which also consists of Rayong and Chachoengsao. The Government has a policy to develop the three provinces on the Eastern Seaboard into a new economic zone.

Chon Buri is the location of Laem Chabang Port, which is one of the busiest deep-sea ports in the world. The port covers an area of 2,536 acres and has been promoted by the Government to be the country's main port, replacing Bangkok Port. As a result of the development of this international deep-sea port, in accordance with the Eastern Seaboard Development Program, Chon Buri has enjoyed steady growth.

Chonburi is about 120 kilometres by road from Suvarnabhumi Airport (BKK), the country's largest International airport. By road, it is accessed from Sukhumvit Road and Motorway 7 from Bangkok. Chonburi is also served by scheduled flights via U-Tapao International Airport (UTP) which is 45 minute drive south of the city.

Chonburi is home to Thailand's largest tourist oriented city, Pattaya (also spelled Phatthaya), It is the only province outside the Bangkok Metropolitan Area to connect by an eight-lane motorway to Bangkok, $80 \mathrm{~km}$ distant. It is home to Thailand's largest and primary seaport, it has a thriving migrant and expatriate population. Due to these factors, the province's population is growing rapidly, with currently some 1.7 million residents (albeit with a large floating or unregistered population) The government is making a US $\$ 43$ billion (S\$59 billion) push behind a plan to quickly expand the economic areas outside Bangkok that will showcase urban centres connected by a high-speed rail network and new motorways. The Eastern 
Economic Corridor (EEC) covers the already established industrial provinces of Chon Buri, Rayong and Chachoengsao, to the east of Bangkok.

Thai economic planners also envision industrial centres that will turn the area, better known as the Eastern Economic Corridor (EEC), into the heartbeat of the vibrant Mekong region, which covers Laos, Cambodia, Vietnam and Myanmar.

Chachoengsao, Chonburi and Rayong Provinces have been designated for the development of the Eastern Economic Corridor (EEC), a pilot project for the economic development of Thailand's Eastern Seaboard. Over the past 30 years, these three provinces have been developed to support the fast growing industries. It was the "eras of industrial revolution". In 1987, Map Ta Phut industrial estate was established and it was the beginning of the development of Thai heavy industry, such as petrochemical, auto and electronics industries. These eras are also called Thailand 3.0. Today, Thailand is ready to move forward to the era of Thailand 4.0.

The EEC area covers over 13,000 Km2. The government has launched measures to support and accelerate the economic growth in the EEC, for instance, measures to develop public utilities, transportation systems, logistics, human resources, and investor's facilitation in the form of One-Stop Service Center.

In the future, the EEC will grow into a modern metropolitan, a hub of trade and investment, a centre for regional transportation and logistics, a significant source for human resources, a tourist attraction and most importantly, the most modern Gateway to Asia. 


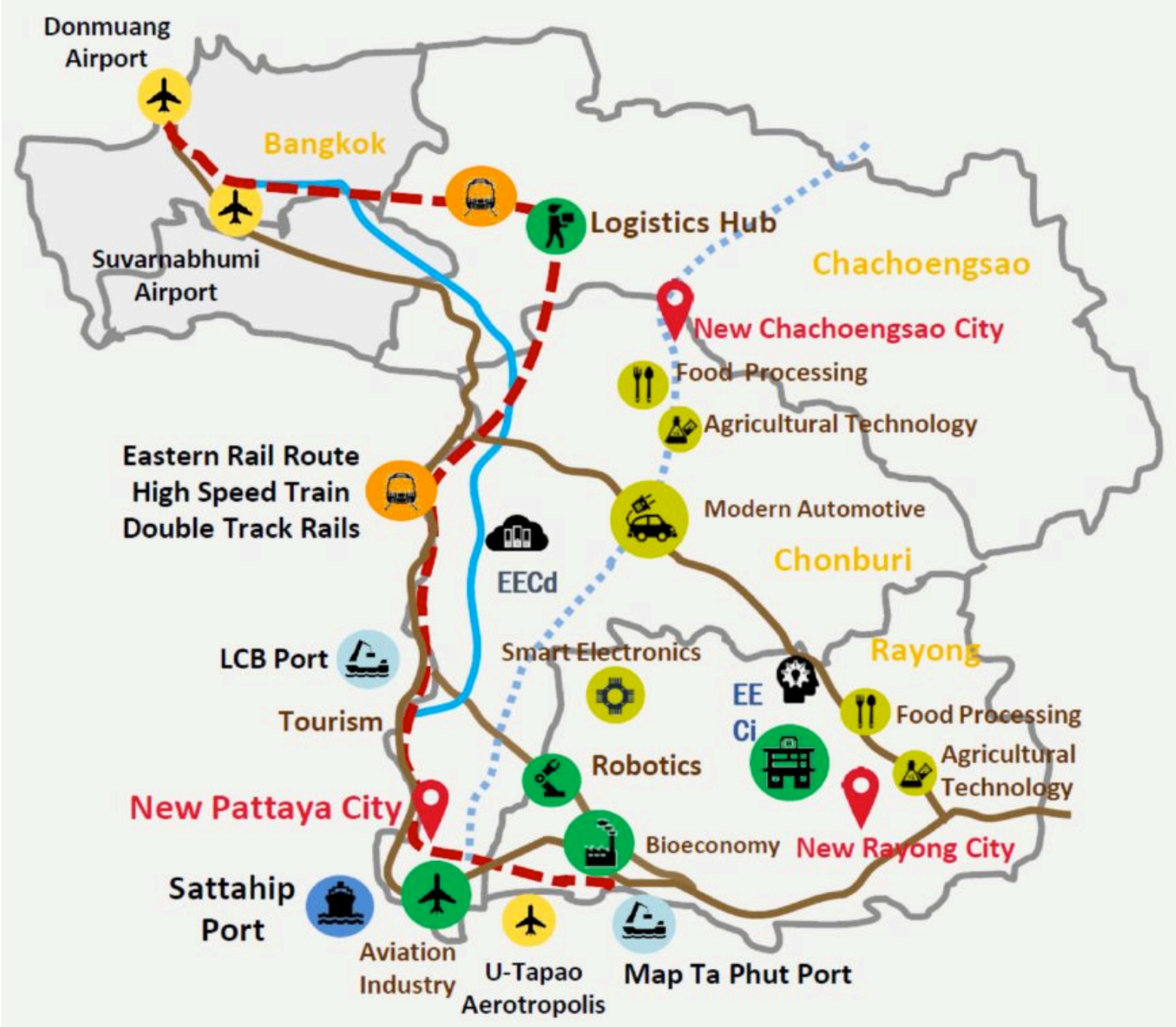

Foreseeing economic potential of Chon Buri, the hospital business is becoming fiercely competitive. The reason is because Chon Buri has become one of the provinces designated as part of Thailand's Eastern Economic Corridor Development Project (EEC) and many more new private hospitals have started up their operation and competing with existing hospitals. Many hospitals exist in Chonburi, both in the public sector and the private sector. Chonburi has one university hospital which is Burapha University Hospital. Its main hospital operated by the Ministry of Public Health is Chonburi Hospital. Hospitals operated by other organisations such as the Thai Red Cross Society (Queen Savang Vadhana Memorial Hospital) and the Royal Thai Navy (Queen Sirikit Naval Hospital) are also located in the province. Private hospitals tend to be significantly present in Mueang Chonburi District, Si Racha District and Pattaya City

Brumgrand (BH) in Thailand largest hospital focusing on medical tourism. Brumbrand has a focus on Middle East market. The outlook for medical tourists from Middle East is not promising. 
Middle East is the largest feeder market for BH, representing 20\% of revenue in 2015. We see further deterioration in Middle East tourist flow as there are increasing evidences of budget tightening in Middle East countries, particularly in UAE. Budget breakeven oil price of Middle East countries ranges from US\$50-130/bbl in 2013. BH's long-serving CEO Mr. Dennis Brown has retired last July. He has been with the company for 12 years, with the last six years being the group CEO of the company. Having served as the CEO of Al Noor Hospital Group in UAE since Oct 2014 until recently, Mr. Ronald Lavater will join and replace Mr. Dennis Brown as the CEO of the company from Sep 2016. Hence the expectation is that BH will still pursue the strategy of focusing on medical tourists from Middle East.

Aikchol should not focus on Middle East patients as they are decreasing and it is difficult to compete with BH. A market to focus on is Indonesia. Currently Singapore hospitals are benefitting from Indonesia market. Singapore however is getting very expensive and the Singapore dollar are rising against the Indonesian rupiah. Aikchol should focus on this market. Many Indonesians are doing wellness health check-ups in Singapore; this is an area for Aikchol to grow. This is also in line with the medical centre strategy.

Thailand remains one of the best places regionally for medical tourism, but the source of growth may be shifting away from the Middle East (tightening government budgets and emerging competition from local operators) to emerging countries (rising incomes and populations with lack of local healthcare facilities).

\section{SECTION 5: The Proposed Strategy:}

The objective is increase profitability and to be Exceptional Excellent Hospital by the year 2019.

In line with the hospital vision and mission Aikchol will also provide one-stop healthcare services with high quality and minimal waiting time.

The proposed 2 strategies are

1. Increase outpatient business by expanding high margin 'private' outpatients and specialist clinics (ie having a medical centre)

2. Venture into medical tourism with a holistic approach.

\section{Outpatient services}

The government subsidised outpatient treatment is to continue. Though low margins, it is profitable and almost assured income. This is to continue as long as there is capacity to handle it. If the time comes when capacity is stretched then capacity should be transferred from subsidised patients to higher margin private patients.

The 'private 'patients outpatient facilities are to be expanded and enhanced. This will start by establishing an outpatient clinic exclusive for private patients; separate from the clinic treating subsidised patients. This will reduce waiting time for private patients. This clinic can commence immediate at the current premises. It is even possible to do it with the same doctors that attend to subsidised patients. It is only the waiting area and waiting time that is different.

The adjacent land acquired can be used to built a medical centre. Construction costs in Thailand are reasonably affordable and the construction costs funding will not be an issue for cash rich Aikchol. The medical centre will have specialist clinics. These clinics can be operated by Aikchol doctors or leased out to outside doctors/medical firms. The quality must be assured. The medical centre will be state of the art and have operating theatres for day surgery. 
The medical centre will raise the profile of Aikchol as a centre of excellence.. The outpatients visiting the clinic will be referred to the specialist clinics in medical centre and the specialist clinics can ward patients in the hospital beds when they require hospitalisation and/or surgery.

The expansion and focus on outpatient/ specialist clinics will benefit from the expected economic growth of Chonburi. The expectation is more companies and MNCs will commence operations in Chonburi and there will be minor influx of foreigners. Aikchol should work with insurance companies to offer medical insurance coverage to the companies. Aikchol should also try to be part of international medical insurances that some foreigners working in Chonburi or the foreigners retiring in Thailand might have.

The medical centre should also focus on wellness medical check up

\section{Medical Tourism}

Aikchol, being in Chonburi and not Bangkok, is in an disadvantaged position. They can overcome this by making it convenient for patients by

a) Providing airport pick up services from Bangkok Suvarnabhumi airport to Aikchol Chonburi. The pic- up will include a nurse or resident doctor to be able to administer basic medical needs on arrival. An ambulance pick up to be provided for patients that could require ambulance.

b) Aikchol should tie up with local 4 or 5 star hotels and service apartments to offer discounted rates for medical tourists.

c) Provide interpreters who can speak Bahasa Indonesia as well as English speaking doctors. 


\section{APPENDIX: FINANCIAL AND OPERATING ANALYSIS}

\section{Aikchol Hospital PCL | Ratios -KeyMetrics}

Annual Standardised in Millions of Thai Baht

\begin{tabular}{|c|c|c|c|c|c|c|}
\hline & $\begin{array}{c}\text { Industry } \\
\text { Median }\end{array}$ & 2016 & 2015 & 2014 & 2013 & 2012 \\
\hline Earnings Quality Score & 58 & 94 & 73 & 94 & 87 & 88 \\
\hline \multicolumn{7}{|l|}{ Healthcare Facilities } \\
\hline Admissions per Bed & - & - & - & - & - & - \\
\hline Surgeries per Admission & - & - & - & - & - & - \\
\hline Occupancy Rate & $80.0 \%$ & $68.0 \%$ & $62.0 \%$ & $70.0 \%$ & $68.0 \%$ & $69.6 \%$ \\
\hline Industry Median & & $80.0 \%$ & $80.0 \%$ & $80.0 \%$ & $80.0 \%$ & $80.0 \%$ \\
\hline $\begin{array}{l}\text { Avg. Length of Stay (Days) } \\
\text { Revenue per Patient Day } \\
\text { (THB) }\end{array}$ & $\begin{array}{l}- \\
-\end{array}$ & - & - & $\begin{array}{l}- \\
-\end{array}$ & - & - \\
\hline \# Hospitals & - & - & - & 2. & 2. & 2. \\
\hline \multicolumn{7}{|l|}{ Profitability } \\
\hline $\begin{array}{l}\text { Gross Profit Margin } \\
\text { Industry Median }\end{array}$ & $39.1 \%$ & $\begin{array}{c}18.9 \% \\
0.391\end{array}$ & $\begin{array}{l}19.2 \% \\
0.391\end{array}$ & $\begin{array}{c}20.2 \% \\
0.391\end{array}$ & $\begin{array}{c}22.4 \% \\
0.391\end{array}$ & $\begin{array}{c}23.5 \% \\
0.391\end{array}$ \\
\hline EBITDA Margin & $20.1 \%$ & $17.8 \%$ & $16.7 \%$ & $18.3 \%$ & $20.7 \%$ & $21.3 \%$ \\
\hline Operating Margin & $14.3 \%$ & $13.9 \%$ & $12.8 \%$ & $14.8 \%$ & $17.3 \%$ & $17.5 \%$ \\
\hline Pretax Margin & $14.6 \%$ & $14.3 \%$ & $13.3 \%$ & $15.1 \%$ & $17.3 \%$ & $17.7 \%$ \\
\hline Effective Tax Rate & $18.3 \%$ & $19.5 \%$ & $19.6 \%$ & $19.7 \%$ & $19.7 \%$ & $22.8 \%$ \\
\hline Net Margin & $11.7 \%$ & $11.5 \%$ & $10.7 \%$ & $12.2 \%$ & $13.9 \%$ & $13.7 \%$ \\
\hline \multicolumn{7}{|l|}{ DuPont/Earning Power } \\
\hline Asset Turnover & 0.74 & 0.97 & 1.00 & 1.09 & 1.10 & 1.14 \\
\hline x Pretax Margin & $14.6 \%$ & $14.3 \%$ & $13.3 \%$ & $15.1 \%$ & $17.3 \%$ & $17.7 \%$ \\
\hline Pretax ROA & $9.3 \%$ & $13.9 \%$ & $13.3 \%$ & $16.4 \%$ & $19.1 \%$ & $20.2 \%$ \\
\hline x Leverage (Assets/Equity) & 1.86 & 1.20 & 1.17 & 1.17 & 1.15 & 1.18 \\
\hline Pretax ROE & $17.1 \%$ & $16.4 \%$ & $15.5 \%$ & $19.1 \%$ & $22.2 \%$ & $24.0 \%$ \\
\hline x Tax Complement & 0.78 & 0.80 & 0.80 & 0.80 & 0.80 & 0.77 \\
\hline ROE & $13.1 \%$ & $13.2 \%$ & $12.5 \%$ & $15.4 \%$ & $17.9 \%$ & $18.5 \%$ \\
\hline x Earnings Retention & 0.70 & 0.48 & 0.45 & 0.17 & 0.50 & 0.57 \\
\hline Reinvestment Rate & $9.5 \%$ & $6.4 \%$ & $5.6 \%$ & $2.7 \%$ & $8.9 \%$ & $10.5 \%$ \\
\hline \multicolumn{7}{|l|}{ Liquidity } \\
\hline Quick Ratio & 1.15 & 3.00 & 3.31 & 3.17 & 3.02 & 2.27 \\
\hline Quick Ratio Industry Median & & 1.15 & 1.15 & 1.15 & 1.15 & 1.15 \\
\hline Current Ratio & 1.58 & 3.15 & 3.52 & 3.37 & 3.25 & 2.50 \\
\hline Current Ratio Industry Median & & 1.58 & 1.58 & 1.58 & 1.58 & 1.58 \\
\hline Times Interest Earned & 9.2 & - & - & - & - & - \\
\hline Cash Cycle (Days) & 65.7 & 21.8 & 22.2 & 19.0 & 13.4 & 12.0 \\
\hline \multicolumn{7}{|l|}{ Leverage } \\
\hline Assets/Equity & 1.86 & 1.20 & 1.17 & 1.17 & 1.15 & 1.18 \\
\hline Debt/Equity & 0.11 & 0.00 & 0.00 & 0.00 & 0.00 & 0.00 \\
\hline \% LT Debt to Total Capital & $4.4 \%$ & $0.0 \%$ & $0.0 \%$ & $0.0 \%$ & $0.0 \%$ & $0.0 \%$ \\
\hline (Total Debt - Cash) / EBITDA & 0.73 & - & - & - & - & - \\
\hline \multicolumn{7}{|l|}{ Operating } \\
\hline A/R Turnover & 4.9 & 11.5 & 11.4 & 12.8 & 15.3 & 15.7 \\
\hline
\end{tabular}




$\begin{array}{lcccccc}\text { Avg. A/R Days } & 74.4 & 32.0 & 32.1 & 28.7 & 23.9 & 23.3 \\ \text { Inv Turnover } & 10.6 & 36.8 & 35.7 & 36.9 & 34.2 & 30.4 \\ \text { Avg. Inventory Days } & 34.3 & 10.0 & 10.3 & 9.9 & 10.7 & 12.0 \\ \text { Avg. A/P Days } & 55.5 & 20.1 & 20.1 & 19.6 & 21.2 & 23.4 \\ \text { Fixed Asset Turnover } & 4.79 & 2.00 & 1.96 & 1.99 & 1.84 & 1.74 \\ \text { WC / Sales Growth } & (4.2 \%) & 1.4 \% & 3.6 \% & 4.8 \% & 6.7 \% & 2.7 \% \\ \text { Bad Debt Allowance (\% of } & & & & & & \\ \text { A/R) } & 3.9 \% & 0.3 \% & 0.3 \% & 0.4 \% & 1.4 \% & 1.3 \% \\ \text { ROIC } & - & 12.7 \% & 12.0 \% & 14.8 \% & 17.2 \% & 17.8 \%\end{array}$

\section{APPENDIX 2}

\section{Income Statement (THB, M)}

\begin{tabular}{|c|c|c|c|}
\hline & LFI & LTM & LFY \\
\hline Total Revenue: & 421.40 & $1,552.78$ & $1,585.50$ \\
\hline EBITDA: & 69.03 & 209.58 & 282.81 \\
\hline EBIT: & 54.17 & 149.39 & 220.86 \\
\hline Income Before Tax: & 54.17 & 149.39 & 226.80 \\
\hline Income After Tax: & 43.32 & 120.46 & 182.54 \\
\hline Income Avail Comm: & 43.32 & 120.46 & 182.54 \\
\hline Dilut Shrs Out Avg: & 149.91 & 149.91 & 149.91 \\
\hline \multicolumn{4}{|l|}{ Income } \\
\hline Bef Tax, Normalized, LFY: & & & 226.80 \\
\hline Aft Tax, Normalized, LFY: & & & 182.54 \\
\hline $\begin{array}{l}\text { Avail Comm, Normalized, } \\
\text { LFY: }\end{array}$ & & & 182.54 \\
\hline \multicolumn{4}{|l|}{ Profitability Ratios (\%) } \\
\hline & LFI & LTM & LFY \\
\hline Gross Profit \% Margin: & 16.81 & 14.40 & 18.94 \\
\hline EBITDA \% Margin: & 16.38 & 13.50 & 17.84 \\
\hline Oper Income \% Margin: & 12.86 & 9.62 & 13.93 \\
\hline Income Bef Tax \% Margin: & 12.86 & 9.62 & 14.30 \\
\hline Income Aft Tax \% Margin: & 10.28 & 7.76 & 11.51 \\
\hline
\end{tabular}


Financial Strength

\begin{tabular}{l|rr} 
& LFI & LFY \\
\hline Quick Ratio: & 2.95 & 3.00 \\
\hline Curr Ratio: & 3.12 & 3.15 \\
\hline LT Debt/Tot Eqty: & 0.00 & 0.00 \\
\hline LT Debt/Tot Assets: & 0.00 & 0.00 \\
\hline Tot Debt/Tot Eqty: & & \\
\hline
\end{tabular}

Management Effectiveness (\%)

\begin{tabular}{|l|rrr|} 
& LFI & LTM & LFY \\
\hline ROC Tot LT Cap: & 3.00 & 8.24 & 12.68 \\
\hline ROE Comm Eqty: & 12.53 & 8.59 & 13.21 \\
\hline ROA Tot Assets: & 10.44 & 7.19 & 11.16 \\
\hline
\end{tabular}

Employees

No. of Employees: $\quad 1,110$ 


\section{Aikchol Hospital PCL | Sector Competitors}

Sector

Competit

ors

\begin{tabular}{|c|c|c|c|c|c|c|c|c|c|}
\hline Name & $\begin{array}{c}\text { LT } \\
\text { Debt/ } \\
\text { Equit } \\
y \\
\end{array}$ & $\begin{array}{c}\text { LT } \\
\text { Debt/ } \\
\text { Capita } \\
1 \\
\end{array}$ & $\begin{array}{c}\text { Liabiliti } \\
\text { es/Equit } \\
y\end{array}$ & $\begin{array}{c}\text { Liab/ } \\
\text { Total } \\
\text { Assets }\end{array}$ & $\begin{array}{l}\text { Gross } \\
\text { Profit }\end{array}$ & EBITDA & $\begin{array}{c}\text { Operati } \\
\text { ng } \\
\text { Profit }\end{array}$ & $\begin{array}{c}\text { Net } \\
\text { Income }\end{array}$ & $\begin{array}{l}\text { Total } \\
\text { Debt }\end{array}$ \\
\hline $\begin{array}{l}\text { Aikchol } \\
\text { Hospital } \\
\text { PCL }\end{array}$ & 0.00 & 0.00 & 19.92 & 16.61 & $\begin{array}{c}300,306 \\
670.00\end{array}$ & $\begin{array}{c}282,810 \\
780.00\end{array}$ & $\begin{array}{c}220,86 \\
2,010.0 \\
0 \\
\end{array}$ & $\begin{array}{c}182,53 \\
7,790.0 \\
0 \\
\end{array}$ & 0.00 \\
\hline $\begin{array}{l}\text { Sector } \\
\text { Average } \\
\text { (Mean) }\end{array}$ & 18.46 & 11.31 & 62.16 & 34.18 & $\begin{array}{l}2,149,97 \\
4,801.18\end{array}$ & $\begin{array}{l}1,472,71 \\
5,044.12\end{array}$ & $\begin{array}{l}1,035,51 \\
0,845.88\end{array}$ & $\begin{array}{c}802,543 \\
379.41\end{array}$ & $\begin{array}{l}2,784,63 \\
7,645.29\end{array}$ \\
\hline $\begin{array}{l}\text { Sector } \\
\text { Median }\end{array}$ & 15.18 & 8.05 & 44.02 & 30.57 & $\begin{array}{c}515,908 \\
010.00\end{array}$ & $\begin{array}{c}452,255 \\
470.00\end{array}$ & $\begin{array}{c}234,705 \\
690.00\end{array}$ & $\begin{array}{c}189,710 \\
970.00\end{array}$ & $\begin{array}{c}81,690,9 \\
50.00\end{array}$ \\
\hline $\begin{array}{l}\text { Bangkok } \\
\text { Dusit } \\
\text { Medical } \\
\text { Services } \\
\text { PCL }\end{array}$ & 46.54 & 28.75 & 91.93 & 47.90 & $\begin{array}{c}22,708,2 \\
88,900.0 \\
0\end{array}$ & $\begin{array}{c}14,684,7 \\
96,810.0 \\
0\end{array}$ & $\begin{array}{l}9,922,95 \\
9,810.00\end{array}$ & $\begin{array}{l}8,386,47 \\
7,660.00\end{array}$ & $\begin{array}{c}31,897,0 \\
57,370.0 \\
0\end{array}$ \\
\hline $\begin{array}{l}\text { Samitivej } \\
\text { PCL }\end{array}$ & 0.00 & 0.00 & 44.02 & 30.57 & $\begin{array}{l}3,428,97 \\
4,220.00 \\
\end{array}$ & $\begin{array}{l}2,284,20 \\
2,550.00 \\
\end{array}$ & $\begin{array}{l}1,726,30 \\
8,550.00 \\
\end{array}$ & $\begin{array}{l}1,366,59 \\
7,790.00 \\
\end{array}$ & $\begin{array}{c}848,820 . \\
00 \\
\end{array}$ \\
\hline $\begin{array}{l}\text { Bangkok } \\
\text { Chain } \\
\text { Hospital } \\
\text { PCL }\end{array}$ & 52.48 & 26.49 & 122.01 & 54.96 & $\begin{array}{l}2,089,44 \\
6,860.00\end{array}$ & $\begin{array}{l}1,802,93 \\
7,710.00\end{array}$ & $\begin{array}{l}1,290,80 \\
3,710.00\end{array}$ & $\begin{array}{c}753,093 \\
450.00\end{array}$ & $\begin{array}{l}4,094,16 \\
4,830.00\end{array}$ \\
\hline $\begin{array}{l}\text { Vibhavad } \\
\text { i Medical } \\
\text { Center } \\
\text { PCL }\end{array}$ & 15.18 & 8.05 & 113.06 & 53.06 & $\begin{array}{l}1,913,16 \\
7,750.00\end{array}$ & $\begin{array}{l}1,484,83 \\
7,570.00\end{array}$ & $\begin{array}{l}1,117,29 \\
1,020.00\end{array}$ & $\begin{array}{c}678,644 \\
410.00\end{array}$ & $\begin{array}{l}3,585,84 \\
7,930.00\end{array}$ \\
\hline $\begin{array}{l}\text { Thonburi } \\
\text { Healthca } \\
\text { re Group } \\
\text { PCL }\end{array}$ & 48.59 & 26.02 & 111.85 & 52.80 & $\begin{array}{l}1,710,24 \\
7,190.00\end{array}$ & $\begin{array}{l}1,163,46 \\
6,100.00\end{array}$ & $\begin{array}{c}927,520 \\
580.00\end{array}$ & $\begin{array}{c}511,151 \\
830.00\end{array}$ & $\begin{array}{l}4,064,17 \\
1,310.00\end{array}$ \\
\hline $\begin{array}{l}\text { Chiang } \\
\text { Mai Ram } \\
\text { Medical } \\
\text { Business } \\
\text { PCL }\end{array}$ & 15.48 & 7.64 & 136.63 & 57.74 & $\begin{array}{l}1,145,25 \\
4,720.00\end{array}$ & $\begin{array}{c}899,339 \\
190.00\end{array}$ & $\begin{array}{c}\text { 696,332, } \\
010.00\end{array}$ & $\begin{array}{c}387,684 \\
540.00\end{array}$ & $\begin{array}{l}1,844,49 \\
6,990.00\end{array}$ \\
\hline $\begin{array}{l}\text { Nonthave } \\
\text { j Hospital } \\
\text { PCL }\end{array}$ & 0.00 & 0.00 & 15.64 & 13.53 & $\begin{array}{c}\text { 645,818, } \\
890.00\end{array}$ & $\begin{array}{c}519,893 \\
980.00\end{array}$ & $\begin{array}{c}387,202 \\
080.00\end{array}$ & $\begin{array}{c}317,385 \\
580.00\end{array}$ & 0.00 \\
\hline $\begin{array}{l}\text { Sikarin } \\
\text { PCL }\end{array}$ & 26.18 & 18.82 & 55.00 & 35.48 & $\begin{array}{c}671,675 \\
830.00 \\
\end{array}$ & $\begin{array}{c}494,357 \\
530.00 \\
\end{array}$ & $\begin{array}{c}234,705, \\
690.00 \\
\end{array}$ & $\begin{array}{c}189,710 \\
970.00 \\
\end{array}$ & $\begin{array}{l}1,267,49 \\
2,040.00 \\
\end{array}$ \\
\hline $\begin{array}{l}\text { e } \\
\text { Hospital } \\
\text { PCL }\end{array}$ & 3.81 & 3.49 & 22.37 & 18.28 & $\begin{array}{c}332,840 \\
240.00\end{array}$ & $\begin{array}{c}284,206 \\
170.00\end{array}$ & $\begin{array}{c}210,014, \\
810.00\end{array}$ & $\begin{array}{c}154,643 \\
510.00\end{array}$ & $\begin{array}{c}81,690,9 \\
50.00\end{array}$ \\
\hline $\begin{array}{l}\text { Thai } \\
\text { Nakarin } \\
\text { Hospital } \\
\text { PCL }\end{array}$ & 0.00 & 0.00 & 21.74 & 17.86 & $\begin{array}{c}515,908 \\
010.00\end{array}$ & $\begin{array}{c}452,255 \\
470.00\end{array}$ & $\begin{array}{c}362,324 \\
470.00\end{array}$ & $\begin{array}{c}290,589 \\
640.00\end{array}$ & 0.00 \\
\hline $\begin{array}{l}\text { Ekachai } \\
\text { Medical } \\
\text { Care PCL }\end{array}$ & 0.00 & 0.00 & 11.46 & 10.28 & $\begin{array}{c}176,964 \\
710.00\end{array}$ & $\begin{array}{c}118,681 \\
490.00\end{array}$ & $\begin{array}{c}93,401,4 \\
90.00\end{array}$ & $\begin{array}{c}75,269,8 \\
00.00\end{array}$ & 0.00 \\
\hline Ratchaph & 12.41 & 11.03 & 40.15 & 28.65 & 136,261 & $99,129,5$ & $87,512,3$ & $67,899,7$ & $64,074,6$ \\
\hline
\end{tabular}




\begin{tabular}{|c|c|c|c|c|c|c|c|c|c|}
\hline $\begin{array}{l}\text { ruek } \\
\text { Hospital } \\
\text { PCL }\end{array}$ & & & & & 640.00 & 60.00 & 60.00 & 70.00 & 00.00 \\
\hline $\begin{array}{l}\text { Dental } \\
\text { Corporati } \\
\text { on PCL }\end{array}$ & 44.11 & 26.26 & 105.39 & 51.31 & $\begin{array}{c}162,858 \\
540.00\end{array}$ & $\begin{array}{c}76,581,6 \\
90.00\end{array}$ & $\begin{array}{c}57,934,6 \\
90.00\end{array}$ & $\begin{array}{c}42,518,0 \\
00.00\end{array}$ & $\begin{array}{c}72,286,5 \\
60.00\end{array}$ \\
\hline $\begin{array}{l}\text { Wattana } \\
\text { pat } \\
\text { Hospital } \\
\text { Trang Co } \\
\text { Ltd }\end{array}$ & 27.38 & 17.45 & 83.65 & 45.55 & $\begin{array}{c}187,470 \\
720.00\end{array}$ & $\begin{array}{c}116,541 \\
320.00\end{array}$ & $\begin{array}{c}81,251,3 \\
20.00\end{array}$ & $\begin{array}{c}72,240,1 \\
30.00\end{array}$ & $\begin{array}{c}188,538 \\
070.00\end{array}$ \\
\hline $\begin{array}{l}\text { Wattana } \\
\text { Karnpaet } \\
\text { PCL }\end{array}$ & 17.50 & 14.39 & 39.93 & 28.54 & $\begin{array}{c}78,098,8 \\
50.00\end{array}$ & $\begin{array}{c}38,913,8 \\
10.00\end{array}$ & $\begin{array}{c}18,422,6 \\
50.00\end{array}$ & $\begin{array}{c}10,889,6 \\
30.00\end{array}$ & $\begin{array}{c}70,052,5 \\
50.00\end{array}$ \\
\hline $\begin{array}{l}\text { Ladprao } \\
\text { General } \\
\text { Hospital } \\
\text { PCL }\end{array}$ & 4.08 & 3.82 & 21.93 & 17.99 & $\begin{array}{c}345,987 \\
880.00\end{array}$ & $\begin{array}{c}233,204 \\
020.00\end{array}$ & $\begin{array}{c}168,837 \\
130.00\end{array}$ & $\begin{array}{c}155,902 \\
950.00\end{array}$ & $\begin{array}{c}108,117 \\
950.00\end{array}$ \\
\hline
\end{tabular}




\begin{tabular}{|c|c|c|c|c|c|}
\hline Name & $\begin{array}{c}\text { LT } \\
\text { Debt/Equity }\end{array}$ & EBITDA & $\begin{array}{c}\text { Operating } \\
\text { Profit }\end{array}$ & Net Income & Total Debt \\
\hline \multirow{3}{*}{$\begin{array}{l}\text { Aikchol } \\
\text { Hospital PCL } \\
\text { Sector } \\
\text { Average } \\
\text { (Mean) } \\
\text { Sector } \\
\text { Median }\end{array}$} & & $282,810,780.00$ & $220,862,010.00$ & $182,537,790.00$ & 0.00 \\
\hline & & $1,472,715,044.12$ & $1,035,510,845.88$ & $802,543,379.41$ & $2,784,637,645.29$ \\
\hline & & $452,255,470.00$ & $234,705,690.00$ & $189,710,970.00$ & $81,690,950.00$ \\
\hline \multirow{2}{*}{$\begin{array}{l}\text { Bangkok } \\
\text { Dusit Medical } \\
\text { Services PCL } \\
\text { Samitivej PCL }\end{array}$} & & $14,684,796,810.00$ & $9,922,959,810.00$ & $8,386,477,660.00$ & $31,897,057,370.00$ \\
\hline & & $2,284,202,550.00$ & $1,726,308,550.00$ & $1,366,597,790.00$ & $848,820.00$ \\
\hline \multirow{6}{*}{$\begin{array}{l}\text { Bangkok } \\
\text { Chain } \\
\text { Hospital PCL } \\
\text { Vibhavadi } \\
\text { Medical } \\
\text { Center PCL } \\
\text { Thonburi } \\
\text { Healthcare } \\
\text { Group PCL } \\
\text { Chiang Mai } \\
\text { Ram Medical } \\
\text { Business PCL } \\
\text { Nonthavej } \\
\text { Hospital PCL } \\
\text { Sikarin PCL }\end{array}$} & & $1,802,937,710.00$ & $1,290,803,710.00$ & $753,093,450.00$ & $4,094,164,830.00$ \\
\hline & & $1,484,837,570.00$ & $1,117,291,020.00$ & $678,644,410.00$ & $3,585,847,930.00$ \\
\hline & & $1,163,466,100.00$ & $927,520,580.00$ & $511,151,830.00$ & $4,064,171,310.00$ \\
\hline & & $899,339,190.00$ & $696,332,010.00$ & $387,684,540.00$ & $1,844,496,990.00$ \\
\hline & & $519,893,980.00$ & $387,202,080.00$ & $317,385,580.00$ & 0.00 \\
\hline & & $494,357,530.00$ & $234,705,690.00$ & $189,710,970.00$ & $1,267,492,040.00$ \\
\hline \multirow{2}{*}{$\begin{array}{l}\text { Rajthanee } \\
\text { Hospital PCL } \\
\text { Thai Nakarin } \\
\text { Hospital PCL }\end{array}$} & & $284,206,170.00$ & $210,014,810.00$ & $154,643,510.00$ & $81,690,950.00$ \\
\hline & & $452,255,470.00$ & $362,324,470.00$ & $290,589,640.00$ & 0.00 \\
\hline \multirow{6}{*}{$\begin{array}{l}\text { Ekachai } \\
\text { Medical Care } \\
\text { PCL } \\
\text { Ratchaphruek } \\
\text { Hospital PCL } \\
\text { Dental } \\
\text { Corporation } \\
\text { PCL } \\
\text { Wattanapat } \\
\text { Hospital } \\
\text { Trang Co Ltd } \\
\text { Wattana } \\
\text { Karnpaet PCL } \\
\text { Ladprao } \\
\text { General } \\
\text { Hospital PCL } \\
\end{array}$} & & $118,681,490.00$ & $93,401,490.00$ & $75,269,800.00$ & 0.00 \\
\hline & & $99,129,560.00$ & $87,512,360.00$ & $67,899,770.00$ & $64,074,600.00$ \\
\hline & & $76,581,690.00$ & $57,934,690.00$ & $42,518,000.00$ & $72,286,560.00$ \\
\hline & & $116,541,320.00$ & $81,251,320.00$ & $72,240,130.00$ & $188,538,070.00$ \\
\hline & & $38,913,810.00$ & $18,422,650.00$ & $10,889,630.00$ & $70,052,550.00$ \\
\hline & & $233,204,020.00$ & $168,837,130.00$ & $155,902,950.00$ & $108,117,950.00$ \\
\hline
\end{tabular}

